\title{
Cartography And Management Of Food-Insecure Areas In Garut
}

\author{
Rina Rifqie Mariana*Mohammad Efendi, MalizalWidaningsih \\ ${ }^{1}$ Department of Industrial TechnologyUniversitas Negeri Malang, Malang, Indonesia \\ ${ }^{2}$ Department of Special EducationUniversitas Negeri MalangMalang, Indonesia \\ ${ }^{3}$ Department of Law ScienceUniversitas GarutGarut, Indonesia \\ "rina.rifqie.ft@um.ac.id ${ }^{1}$, mohammadefendi.fip@um.ac.id ${ }^{2}$, widamalizal@yahoo.com ${ }^{3}$
}

Article History: Received: 11 January 2021; Accepted: 27 February 2021; Published online: 5 April 2021

\begin{abstract}
The objective of this research was to investigate the situation of food insecurity and its handling in Garut District, West Java, Indonesia. An analysis based on the national food insecurity indicators and the Food Insecurity Atlas has identified food-insecure areas, resulting in nine indicators reflecting the three pillars of food security, i.e.,food availability, access to food, and use of food. Results on food insecurity status show that priority 1 belongs to the nine villages under study 1 . The local government has imposed five policies to address food insecurity, i.e., 1) setting up a monthly program called the Food and Nutrition Security System, 2) direct assistance in the form of food staples, 3) developing the Food Security and Vulnerability Atlas, 4) improving food access, and 5) developing self-sufficient villages. These attempts are quite efficient. After three years, more areas have moved from Priority 1 to Priority 3 in food security.
\end{abstract}

Keywords: food security; an indicator of vulnerability; manipulation; mapping

\section{INTRODUCTION}

Food is a basic entitlement that can determine human life quality(Beddington et al., 2012). Fulfilling food needs is necessary to create a prosperous society, and to that end, it requires the support andinvolvement of stakeholders. The problem of food insecurity is multi-dimensional, encompassing social, economic, and political dimensions, and therefore the approach to its solution should be comprehensive (Maxwell \& Slater, 2003 and Chang, Chatterjee \& Kim 2014). For instance, a very fertile region called Andhra Pradesh eventually faced a problem of severe food shortage due to a massive conversion of agricultural land for housing and industrial purposes(Brown, 2005). This condition occurred because there was a fatal error in the policy setting.

Awasthi \& Singh (2010)explained that social, economic, political, and technological factors affect food insecurity and indicators such as food availability, food access, and food utilization. There are about 200 definitions of food security indicators, but all can be summarised into three dimensions: food availability, food access, and food utilization (Hoddinott, 1999). According to the Indonesian Food Security Agency (BKP, 2015), the three dimensions are divided into nine indicators, i.e., analysis of normative consumption/cereal and tuber availability, population below the poverty line, population without access to electricity, population without access to safe water, village inaccessible to four-wheeled vehicles, life expectancy at birth, population living $>5$ $\mathrm{km}$ to the community health center(puskesmas), infant mortality rate, and female illiteracy. These nine indicators are considered the most appropriate to measure food insecurity in an area.

Based on the annual performance report of BPS(2014), Indonesia is one of the ten countries in the world with the largest land area, reaching 191.09 million hectares of land, and currently has 90 million farmers or approximately $45 \%$ of the total population in $2015-255,154,166$ inhabitants. Besides, Indonesia also has a comparative advantage as an agrarian and maritime country (Timmer, 2002). Indonesia's diversity and wealth of natural resources support healthy food consumption and balanced nutrient intake. By this very fact, food insecurity should not have happened in Indonesia.

Nevertheless, food security is determined by the abundant supply of food (Narayanan \& Gerber, 2017). Farmers as food producers are also a critical factor in enhancing food security. Barrett(2010), FAO, IFAD \& WFP(2013), and Nelson, Bereuter \& Glickman(2014) explained that food security at the household level is achievable if the households can obtain sufficient, safe, and nutritious food, either through self-production or purchase. The is in line with Bishwajit et al.(2013), stating that food security can be improved if people have physical, social, and economic access to adequate and nutritious food to support healthy and productive living. To that end, food trade should be directed to the benefit and welfare of society.

West Java is the most populous province in Indonesia (18.11\%), with a total population of 43,021,826 people (Sub Direktorat Statistik Demografi, 2015). It has nine cities and 17 districts. Based on data from the Central Bureau of Statistics(BPS, 2014), the number of economically deprived households in West Java is close to 5 million.GarutDistrict is one of the areas with the highest poverty rate.

GarutDistrictcomprises 42 sub-districts and 432 villages. GarutDistrict has a great deal of land suitable for agriculture with an estimated 100.7 million ha, consisting of 24.5 million ha wetlands, 25.3 million ha drylands, and 50.9 million ha croplands. The agricultural sector remains a prime mover of the national economy. According to BPS (2014), GarutDistrict has some comparative advantages, such as relatively fertile soil suitable for various agricultural uses and many human resources, which have implications for diverse agrarian systems and high-value agricultural commodities. The agricultural sector is dominatedby food crops followed by 
plantations, livestock, forestry, and fisheries (BPS, 2014).Despite the excellence, several villages in GarutDistrictare still classified as food insecure areas. There are nine villages categorized in Priority 1 - towns considered the most vulnerable to food insecuritymeasured based on the nine indicators above.

According to their respective duties and authorities, the government and the community should work together to determine the priority of handling food insecurity. They should explore the root of the problem by examining in depth through research that generates accurate data on the situation and conditions of food security starting from the household level to the national level. The data then can be used as the basis for strategic policy-making to overcome various food problems.

\section{METHOD}

This study was conducted through three steps: formulation of food insecurity indicators, determination of areas of Priority 1 of food insecurity, and identification of the causes of food insecurity. The title of food insecurity at the village level was made based on FIA's indicators (Food Insecurity Atlas), used in the national food security analysis.

The researchers referred to the 2015 Food Security and Vulnerability Atlas of West Java (World Food Programme, 2015) to select the research sites and obtain data about potential food insecurity in Garutdistrict, Indonesia. The chosen areas are classified as Priority 1 of food insecurity (most vulnerable to food and nutrition crises). Nine villages were selected, namely Pancasarua. Tegalega, Simpang, Margamulya, Godog, Sekarwangi, Sukajaya, Sukanagara, and Purwajaya.

Data collection was done through the following steps:

(1) Documentation in 2016 from the Central Bureau of Statistics (BPS), village offices and Food Security Agency (BKP) of GarutDistrict;

(2) Interviews with stakeholders including the community to explore information on indicators of food insecurity in the region and to follow up the documents available at BPS, BKP, or village offices;

(3) Direct observation by recordingthe facilities, infrastructure, agricultural conditions of the areas under study systematically;

(4) Questionnaires were administered to residents of the areas under study to elicit information about poverty and other relevant information.

\section{RESULTS}

\section{Analysis of normative consumption}

The results of normative consumption analysis in the nine locations in Garutdistrict(see Table 1) show that each village's food availabilityis classified into the 'large surplus' category. In other words, the amount of cereal produced by each village is more than enough to meet the food needs of its local population.Nevertheless, based on interviews with each ofthe nine village chiefs and supported by population data from the sub-district office, most of the rural areas are farmworkers, not landowners.

\section{Population below the poverty line}

Table 2 shows that the population living below the poverty line in all villages under study belongs to the 'highly vulnerable' category (11 out of 13 indicators). The poverty indicators refer to 14 standard poverty measures(BPS, 2014): 1) house floor area of less than $8 \mathrm{~m}^{2} /$ person, 2) house with dirt or cheap wood floor, 3) house wall made of bamboo or low-quality wood, 4) low sewage system, 5) no electricity, 6) unprotected springs or rivers as drinking water sources, 7) firewood or charcoal as daily cooking fuels, 8) low protein consumption (once a week), 9) eating once to twice a day, 10) buying one set of new clothes in a year (at maximum) for every household member, 11) no health budget, 12) the head of household: farmer (farm area of $500 \mathrm{~m}^{2}$ ), farmworker, fisherman, construction worker and others who earn Rp 600,000/month, 13) agricultural household heads with only primary education, and 14) no easy-to-sell items with a minimum price of Rp 500,000. The 'pre-prosperous' category includes households that exhibit all ofthe 14 measures. Homes that exhibit 11-12 characteristics belong to the 'prosperous 1' category. The 'prosperous 2' category includes households that display 9-10 attributes.

The data collected from village documents, observation, and questionnaires administered to $10 \%$ of each village population reveal that, on average, the residents of the nine villages under study live below the poverty line by exhibiting 11 to 13 indicators of poverty.Among the nine villages, Godog, Purwajaya, andSimpang are the areas with the highest number of poor people, i.e., above $80 \%$.

\section{Villages without access to electricity and safe water}

The number of households in the nine villages that do not have access to electricity and clean water can be found in Table 3.The percentage of households without electricity access shows that only one villagebelongs to the 'secure' category. Based on the observation, more than $50 \%$ of the population lives without electricity because most towns have no electricity access. Regarding access to safe water, most households in the areas under study still use river water for bathing, drinking, and cooking. 


\section{Villages inaccessible to four-wheeled vehicles}

Three out of nine villages under study belong to the 'vulnerable' category due to poor road conditions. These areas do not have asphalt roads, only narrow dirt roads that can merely be traveledby two-wheeled vehicles and are often impassable in the rainy season (see Figure 1). As a result, access to public facilities is limited and difficult.

\section{Life expectancy and infant mortality rate}

As shown in Table 4, in general, the life expectancy of the nine villages under study belongs to the 'secure' category. Based on the infant mortality rate analysis in the nine villages, all villages belong to the 'highly secure' category.

\section{Population living $>5 \mathrm{~km}$ away from puskesmas}

The analysis results of the residents of the nine villages that live $>5 \mathrm{~km}$ from puskesmas (community health care centers) showed that only one town (Godog) belongs to 'highly secure.' However, two villages (Sukanagara and Purwajaya) are still classified as 'highly vulnerable' because the travel distance to reach the closestpuskesmas is between 17 to $23 \mathrm{~km}$.

\section{Illiterate population}

The analysis results show that the illiterate population in the villages under study is deficient. The percentage of illiterate people is between $0.23 \%$ and $1.52 \%$ and thus classified as 'highly secure.' The classification scheme is as follows: $>-70 \%=$ highly vulnerable, $60-<70 \%=$ vulnerable, $50-<60 \%=$ less vulnerable, $40<50 \%=$ relatively secure, $30-<40 \%=$ secure, $<30 \%=$ highly secure. Among the nine villages, Simpang has the highest illiterate population, i.e., 86 out of 5661 people aged above 47 are illiterate.

\section{Policy on handling food insecurity in Garutdistrict}

Some policies and operational steps implemented to handle food insecurity in Garutdistrict, Indonesia,have referred to central government policies based on the 2015 Government Institution Performance Accountability Report (LAKIP) (BKPD, 2015). The actions include 1) monitoring and early detection system in anticipating the occurrence of food insecurity through a monthly program called Food and Nutrition Security System (SKPG), 2) direct assistance in the form of food staples to impoverished areas,3) preparation of food security and vulnerability atlas (FSVA) for setting operational steps and implementing work programs in each region with its different needs, 4) improving access to food by increasing agricultural production and working with the society, government and universities, and 5) development of food self-sufficient villages. The village empoweredis then given a responsibility to foster three food-insecure villages in the surroundings.

\section{DISCUSSION}

Of the nine villages classified as Priority 1offood insecurity, the food availability is in the 'high surplus' category. However, by the fourteen criteria for the poverty line established by the Indonesian Central Statistics Agency (BPS), the nine areas under study are considered too deprived.This contradictory result suggests a severe problem in post-harvest management.Turyahabwe, Kakuru, Tweheyo\& Tumusiime (2013) and Arouna, Lokossou, Wopereis, Bruce-Oliver, \& Roy-Macauley (2017), the availability of food cannot guarantee the food security of an area. Sufficient food availability has tobe supported by the availability of other infrastructure such as roads, electricity, and so forth. Food production is also not the sole determinant of food security, but merely one of the decisive factors (Mun'im, 2016). The factors affecting food security in food surplus areas are food access and utilization, not food availability. It is in line with Suryana (2005) stating that national food availability adequacy does not guarantee the adequacy of consumption at the household or individual level, mainly due to a flawed transportation system. According to the 2016-2020 United Nations Partnership for Development Framework (UNPDF) (United Nations, 2015), 103 million out of 255,154,166 people (43.5\%) in Indonesia live under the poverty line or below USD 2 per day, and $60 \%$ of the needy are in rural areas. However, based on the fourteen standard poverty measuresabove, only $10.86 \%$ of Indonesians live below the poverty line (BPS, 2016). Shaefer, Wu, \& Edin (2016) stated that there are four welfare indicators in the United States of America, namely: 1) life expectancy, 2) infant mortality, 3) murder, and 4) education.

Poor road infrastructure is undoubtedly another contributing factorto poverty in the nine villages because the communities are isolated and do not enjoygovernment development programs' benefits. A good and reliable transport network ispivotal to facilitating the organizations to have access to goods and services (Nainggolan, Hapsari, \&Indrawati, 2016). As in Brazil, from 2004 to 2013, 22.6\% of the population experienced food insecurity because of the unequal distribution of food throughout the region and state (Gubert, dos Santos, Santos, \& Pérez-Escamilla, 2017).The principal cause to this is the difficulty of transportation to ply on village roads in poor condition. The policies established in Tanzania can be used as a reference (see Bolwig, Ponte, Du 
Toit, Riisgaard, \& Halberg, 2010 and Von Braun, 2007), i.e., projects by the Southern Agricultural Growth Corridor of Tanzania (SAGCOT) aiming to develop 350,000 hectares of agricultural land for commercial production of international markets in the next 20 years.

As in South Korea, the government has introduced a policy that reflects a market-based approach, which has been proven effective in reducing the poverty gap from 6.8 to 39.6\% in 2016 by encouraging the informal sector to provide better social services(Choi, Choi, \& Choi, 2016). At the micro-level, the policies should improve agricultural productivity by increasing the capital, marketing effort, and quality of agricultural produce.In Tanzania, food security is highly dependent on the food supply systems and the food production potential in rural areas (Wenban-Smith, Faße, \& Grote, 2016). Dawson, Martin \& Sikor (2016) further pointed out that a traditional farming system orientating towards subsistence and local trade needs to adopt improved seed varieties to increase production and income. Therefore, Indonesia's government, especially the local government of Garut District, should partner with various concerned elements to develop superior agricultural varieties, not only in quantity but also in quality. As in Africa, the improvement of seed varieties, particularly rice, impacts food security and poverty alleviation (see Sanchez, Denning, \& Nziguheba, 2009; Jayne \& Rashid, 2013; draftJohnson, Suzuki, Sakurai, \& Otsuka, 2014). Rice is considered an essential agricultural product, the most significantfood energy source, and a staple food for more than 750 million people (Shrestha, Deb, \& Bui, 2016).

Other factors responsible for severe food insecurity are limited access to medical care, safe water, and electricity. Most people in the nine villages are being restricted to adequate water and electricity supply. There is a significant influence of the availability and quality of clean water on a region's poverty(Soussan, 2004). This is in line with Kumar \& Singh (2005), stating that acute water scarcity can affect a country's economic condition. When access to clean water is better, then land and irrigation will improve. People living in rural areas with limited facilities are more likely to have poor health due to various constraints (Wibowo, 1992). Bad health outcomes lack access to necessary health facilities such as puskesmas or hospitals (Nainggolan, Hapsari, \& Indrawati, 2016). In Pakistan, the primary cause of food insecurity and unemployment, and inadequate education, is poor health (Abdullah et al., 2017). Research conducted in 11 countries in Asia, including Indonesia, on the causes of poverty revealed that one indicator of poverty is the family budget on health care, whichis still below the standards(van Doorslaer et al., 2006).

The local government of Garut district has devoted considerable effort to alleviate poverty and food insecurity through short and long-term social welfare programs set out in the Garut Strategic Plan, such as improving food access, providing basic needs assistance, and developing independent villages. The world has a long history of food aid programs to the poor in various countries, including in Washington (see Subbarao, 1997; Ravallion, 2003; von Braun, 1995; Barrett, 2002).Nevertheless, these aid projects to the poor should be based on appropriate strategies and kept under control. As in Kenya, for many years, the Kenyan government invested in food security projects to combat poverty by involving 15 development partners. However, the project ultimately failed because only 5 out of 36 funded groups were active, and the rest were not traceable and remained in low and food insecurity status (Wabwoba \& Wakhungu, 2013). In Hong Kong, the government spent a considerable amount on social assistance provision and applied strict controls on the recipients (Lai, 2017).

\section{CONCLUSION}

The status of food insecurity in the nine villages under studywas determined by nine indicators related to food availability, food access, and food utilization. Various food insecurity dimensions cause food insecurity in those villages classified as Priority 1, but the primary cause is the population living below the poverty line.

The five social welfarepolicies above effectively reduce food insecurity because there has been a significant positive change - evaluated in the last three years. Based on the World Food Programme (2015) study, 16 villages were categorized as Priority 1 of food insecurity in 2013, and nine were left in 2016 - some have shifted to Priority 2 and Priority 3.

Acknowledgments

We wish to thank the Food Security Agency (BKP) of Garut and the Provincial and District Planning Board (BAPPEDA) of GarutDistrict for their assistance and support during the data collection.

\section{REFERENCES}

1. Abdullah, Zhou, D., Shah, T., Ali, S., Ahmad, W., Din, I. U., \& Ilyas, A. (2017). Factors affecting household food security in rural northern hinterland of Pakistan. Journal of the Saudi Society of Agricultural Sciences. https://doi.org/10.1016/j.jssas.2017.05.003

2. Arouna, A., Lokossou, J. C., Wopereis, M. C. S., Bruce-Oliver, S., \& Roy-Macauley, H. (2017). Contribution of improved rice varieties to poverty reduction and food security in sub-Saharan Africa. Global Food Security, 14, 54-60. https://doi.org/10.1016/j.gfs.2017.03.001

3. Awasthi, M. K., \& Singh, S. (2010). System analysis of food security situation in India. Journal of Food Security, 1(1), 24-32. 
4. Barrett, C. B. (2002). Chapter 40: Food security and food assistance programs. In Handbook of agricultural economics (Vol. 2, pp. 2103-2190). Elsevier. Retrieved from http://www.sciencedirect.com/science/article/pii/S1574007202100272

5. Barrett, C. B. (2010). Measuring food insecurity. Science, 327(5967), 825-828. https://doi.org/10.1126/science. 1182768

6. Beddington, J. R., Asaduzzaman, M., Clark, M. E., Bremauntz, A. F., Guillou, M. D., Jahn, M. M., ... Wakhungu, J. (2012). The role for scientists in tackling food insecurity and climate change. Agriculture \& Food Security, 1, 10. https://doi.org/10.1186/2048-7010-1-10

7. Bishwajit, G., Sarker, S., Kpoghomou, M.-A., Gao, H., Jun, L., Yin, D., \& Ghosh, S. (2013). Selfsufficiency in rice and food security: a South Asian perspective. Agriculture \& Food Security, 2(1), 10. https://doi.org/10.1186/2048-7010-2-10

8. BKP (Badan Ketahanan Pangan). (2015). Data statistik ketahanan pangan tahun 2014. Jakarta: Badan Ketahan Pangan (BKP). Retrieved http://bkp.pertanian.go.id/tinymcpuk/gambar/file/data_statistik_kp_2014_new.pdf

9. BKPD (Badan Ketahanan Pangan Daerah). (2015). Laporan akuntabilitas kinerja instansi pemerintah: badan ketahanan pangan daerah provinsi Jawa Barat tahun 2015 (p. 53). BKPD (Badan Ketahanan Pangan Daerah) Provinsi Jawa Barat. Retrieved from http://bkpd.jabarprov.go.id/wp-content/uploads/2014/07/LAKIP-BKPD-2015-.pdf

10. BPS (Badan Pusat Statistik). (2014). Jumlah dan persentase penduduk miskin, garis kemiskinan, indeks kedalaman kemiskinan (P1), dan indeks keparahan kemiskinan (P2) menurut provinsi. Retrieved from http://www.bps.go.id/linkTabelStatis/view/id/1488

11. BPS (Badan Pusat Statistik). (2016). Statistik keuangan pemerintah provinsi 2012-2015.

12. Brown, L. R. (2005). Outgrowing the Earth: The Food Security Challenge in an Age of Falling Water Tables and Rising Temperatures (UNABRIDGED VERSION edition). New York: W. W. Norton \& Company.

13. Chang, Y., Chatterjee, S., \& Kim, J. (2014). Household finance and food insecurity. Journal of Family and Economic Issues, 35(4), 499-515. https://doi.org/10.1007/s10834-013-9382-Z

14. Choi, J.-S., Choi, S.-A., \& Choi, J.-K. (2016). Poverty reduction effectiveness of public income transfers in South Korea in the wake of the global financial crises: a panel-data analysis. Asia Pacific Journal of Social Work and Development, 26(1), 46-60. https://doi.org/10.1080/02185385.2016.1157033

15. Dawson, N., Martin, A., \& Sikor, T. (2016). Green revolution in Sub-Saharan Africa: implications of imposed innovation for the wellbeing of rural smallholders. World Development, 78, 204-218.

16. deGraft-Johnson, M., Suzuki, A., Sakurai, T., \& Otsuka, K. (2014). On the transferability of the Asian rice green revolution to rainfed areas in sub-Saharan Africa: an assessment of technology intervention in Northern Ghana. Agricultural Economics, 45(5), 555-570. https://doi.org/10.1111/agec.12106

17. FAO, IFAD, \& WFP. (2013). The state of food insecurity in the world 2013: the multiple dimensions of food security. Rome: FAO.

18. Hoddinott, J. (1999). Operationalizing household food security in development projects: an introduction. Technical Guide, 1, 1-19.

19. Jayne, T. s., \& Rashid, S. (2013). Input subsidy programs in sub-Saharan Africa: a synthesis of recent evidence. Agricultural Economics, 44(6), 547-562. https://doi.org/10.1111/agec.12073

20. Kumar, M. D., \& Singh, O. P. (2005). Virtual water in global food and water policy making: is there a need for rethinking? Water Resources Management, 19(6), 759-789. https://doi.org/10.1007/s11269-005-3278-0

21. Lai, D. W. L. (2017). A comparative study of social assistance systems in Macao and Hong Kong. Asia Pacific Journal of Social Work and Development, 27(1), 39-52. https://doi.org/10.1080/02185385.2017.1310054

22. Maxwell, S., \& Slater, R. (2003). Food policy old and new. Development Policy Review, 21(5-6), 531-553. https://doi.org/10.1111/j.1467-8659.2003.00222.x

23. Mun'im, A. (2016). Analisis pengaruh faktor ketersediaan, akses, dan penyerapan pangan terhadap ketahanan pangan di kabupaten surplus pangan: pendekatan partial least square path modeling. Jurnal Agro Ekonomi, 30(1), 41-58.

24. Nainggolan, O., Hapsari, D., \& Indrawati, L. (2016). Pengaruh akses ke fasilitas kesehatan terhadap kelengkapan imunisasi baduta (analisis riskesdas 2013). Media Penelitian Dan Pengembangan Kesehatan, 26(1), 15-28. https://doi.org/10.22435/mpk.v26i1.4900.15-28

25. Narayanan, S., \& Gerber, N. (2017). Social safety nets for food and nutrition security in India. Global Food Security. https://doi.org/10.1016/j.gfs.2017.05.001 
26. Nelson, G. C., Bereuter, D., \& Glickman, D. (2014). Advancing global food security in the face of a changing climate. Chicago: Chicago Council on Foreign Affairs.

27. Ravallion, M. (2003). Targeted transfers in poor countries: revisiting the tradeoffs and policy options (Vol. 3048). World Bank Publications.

28. Sanchez, P. A., Denning, G. L., \& Nziguheba, G. (2009). The African Green Revolution moves forward. Food Security, 1(1), 37-44. https://doi.org/10.1007/s12571-009-0011-5

29. Shaefer, H. L., Wu, P., \& Edin, K. (2016). Can poverty in America be compared to conditions in the world's poorest countries? National Poverty Center (NPC) Working Paper Series, (16-07).

30. Shrestha, S., Deb, P., \& Bui, T. T. T. (2016). Adaptation strategies for rice cultivation under climate change in Central Vietnam. Mitigation and Adaptation Strategies for Global Change, 21(1), 15-37. https://doi.org/10.1007/s11027-014-9567-2

31. Soussan, J. (2004). Water and poverty fighting poverty through water management.

32. Sub Direktorat Statistik Demografi. (2015). Penduduk indonesia hasil SUPAS 2015. Jakarta: Badan Pusat Statistik. Retrieved from http://bps.go.id/website/pdf_publikasi/Penduduk-Indonesia-hasilSUPAS-2015_rev.pdf

33. Subbarao, K. (1997). Public works as an anti-poverty program: An overview of cross-country experience. American Journal of Agricultural Economics, 79(2), 678-683. https://doi.org/10.2307/1244171

34. Suryana, A. (2005). Kendala, tantangan dan kebijakan dalam upaya mewujudkan pemantapan ketahanan dan kemandirian pangan nasional ke depan (Vol. 12). Presented at the Semiloka Nasional Bidang IPTEK, Jakarta, Indonesia: Dewan Pimpinan Pusat Ikatan Mahasiswa Muhamadiyah (DPPIMM).

35. Timmer, C. P. (2002). Chapter 29: Agriculture and economic development. In Handbook of agricultural economics (Vol. 2, pp. 1487-1546). Elsevier. Retrieved from http://www.sciencedirect.com/science/article/pii/S1574007202100119

36. Turyahabwe, N., Kakuru, W., Tweheyo, M., \& Tumusiime, D. M. (2013). Contribution of wetland resources to household food security in Uganda. Agriculture \& Food Security, $2,5$. https://doi.org/10.1186/2048-7010-2-5

37. United Nations. (2015). United Nations Partnership for Development Framework (UNPDF), 20162020: Fostering sustainable and inclusive development, Republic of Indonesia and the United Nations System in Indonesia. Jakarta: Government of the Republic of Indonesia and the United Nations in Indonesia.

38. van Doorslaer, E., O'Donnell, O., Rannan-Eliya, R. P., Somanathan, A., Adhikari, S. R., Garg, C. C., ... Zhao, Y. (2006). Effect of payments for health care on poverty estimates in 11 countries in Asia: an analysis of household survey data. The Lancet, 368(9544), 1357-1364. https://doi.org/10.1016/S0140-6736(06)69560-3

39. von Braun, J. (1995). Agricultural commercialization: impacts on income and nutrition and implications for policy. Food Policy, 20(3), 187-202. https://doi.org/10.1016/0306-9192(95)000135

40. Wabwoba, M. S. N., \& Wakhungu, J. W. (2013). Factors affecting sustainability of community food security projects in Kiambu County, Kenya. Agriculture \& Food Security, 2, 9. https://doi.org/10.1186/2048-7010-2-9

41. Wenban-Smith, H., Faße, A., \& Grote, U. (2016). Food security in Tanzania: the challenge of rapid urbanisation. Food Security, 8(5), 973-984. https://doi.org/10.1007/s12571-016-0612-8

42. Wibowo, A. (1992). Pemanfaatan pelayanan antenatal: faktor-faktor yang mempengaruhi, dan hubungannya dengan bayi berat Lahir Rendah. FKM-UI.

43. World Food Programme. (2015). Food Security and Vulnerability Atlas of West Java 2015. 